\title{
War, Lies, and the News Photo: Second World War Photographic Propaganda in PM's Weekly (1940-1941)
}

\section{Carol Payne}

Volume 39, numéro 2, 2014

Photography and War

La photographie et la guerre

URI : https://id.erudit.org/iderudit/1027747ar

DOI : https://doi.org/10.7202/1027747ar

\section{Aller au sommaire du numéro}

\section{Éditeur(s)}

UAAC-AAUC (University Art Association of Canada | Association d'art des universités du Canada)

\section{ISSN}

0315-9906 (imprimé)

1918-4778 (numérique)

\section{Découvrir la revue}

Citer cet article

Payne, C. (2014). War, Lies, and the News Photo: Second World War Photographic Propaganda in PM's Weekly (1940-1941). RACAR : Revue d'art canadienne / Canadian Art Review, 39(2), 29-42.

https://doi.org/10.7202/1027747ar

\section{Résumé de l'article}

Cet article explore un épisode remarquable de l'histoire photographique et journalistique pendant la Seconde Guerre mondiale : la reproduction et le traitement des images de propagande des pays de l'Axe par le journal progressiste new-yorkais $P M$ en 1940-1941, à la veille de l'entrée des États-Unis dans le conflit. La stratégie éditoriale de $P M$ communique tant une conscience aiguë des stratégies de propagande de l'époque qu'une forme novatrice de contre-propagande. En effet, $P M$ a tenté d'inoculer son lectorat états-unien contre les effets de la propagande nazie et fasciste en reproduisant les mêmes images qui étaient au coeur de leurs protestations, mais en détournant leur intention originale par des légendes et des textes d'accompagnement qui attiraient l'attention sur l'artifice photographique et sur la manipulation contextuelle des images. En même temps, les rédacteurs de $P M$, en situant leur publication comme un guide fiable dans le dédale de vérités et de mensonges des photographies de guerre, exposaient leurs propres images de propagande photographique comme preuves de leur crédibilité, et ajoutaient ainsi une nouvelle strate de persuasion.
Tous droits réservés @ UAAC-AAUC (University Art Association of Canada | Association d'art des universités du Canada), 2014
Ce document est protégé par la loi sur le droit d'auteur. L'utilisation des services d'Érudit (y compris la reproduction) est assujettie à sa politique d'utilisation que vous pouvez consulter en ligne.

https://apropos.erudit.org/fr/usagers/politique-dutilisation/ 


\title{
War, Lies, and the News Photo: Second World War Photographic Propaganda in PM's Weekly (1940-194I)
}

\author{
Carol Payne, Carleton University
}

\begin{abstract}
Résumé
Cet article explore un épisode remarquable de l'histoire photographique et journalistique pendant la Seconde Guerre mondiale : la reproduction et le traitement des images de propagande des pays de l'Axe par le journal progressiste new-yorkais PM en 1940-194I, à la veille de l'entrée des États-Unis dans le conflit. La stratégie éditoriale de PM communique tant une conscience aiguë des stratégies de propagande de l'époque qu'une forme novatrice de contre-propagande. En effet, PM a tenté d'inoculer son lectorat états-unien contre les effets de la propagande nazie et fasciste en reproduisant les mêmes images qui étaient au cœur de leurs protestations, mais en détournant leur intention originale par des légendes et des textes d'accompagnement qui attiraient l'attention sur l'artifice photographique et sur la manipulation contextuelle des images. En même temps, les rédacteurs de $P M$, en situant leur publication comme un guide fiable dans le dédale de vérités et de mensonges des photographies de guerre, exposaient leurs propres images de propagande photographique comme preuves de leur crédibilité, et ajoutaient ainsi une nouvelle strate de persuasion.
\end{abstract}

The thing to bear in mind in "reading" photographs is that none of them can tell the full truth...

\section{Ralph Steiner ${ }^{1}$}

$\mathrm{W}_{\mathrm{i}}$ th conflicts being waged overseas and an increasingly animated domestic debate on intervention, war was the story in US journalism during the early autumn of 1940. In New York City, the country's largest market for daily news and the arbiter of national journalistic trends, newspapers competed over their coverage of the fighting and hotly debated the role the United States should play in the conflict in the months before Pearl Harbor. Established papers-the New York Times, the New York Herald Tribune, the World-Telegram, and the Post-as well as tabloids such as the Daily News and the Daily Mirror flooded the market with accounts of the war. Added to the fray was $P M$, New York's newest daily, which had been founded earlier that year. Named for its afternoon delivery, $P M$ was known-and is still remembered today-for both its progressive politics and its innovative approach to journalism, including an extensive use of the photograph. Within its pages, war was more often than not the focal point of news, commentary, and pictorials.

The 22 September 1940 edition typifies PMs early coverage of the Second World War in many respects. We can imagine readers thoughtfully poring over the newspaper's war reporting in its main "hard news" section, then turning to the more diverting Sunday arts and leisure section, PM's Weekly. But on this particular Sunday, PM's Weekly offered its readers little in the way of relaxation. Instead, it opened with a jolt. The front cover features a full-page photograph of Adolph Hitler (fig. 1). ${ }^{2}$ While images of the Nazi leader were hardly novel in American papers of the time, this is not a typically small identifying shot of Hitler seen in a military context or contrasted to Allied leaders. Rather, PM's Weekly presents Hitler in a seemingly casual and intimate stance in the threshold of a doorway, his body filling the centre of the picture frame. Three young children surround him, clutching his hands comfortably as if posing for a family snapshot. This standard example of Nazi photographic propaganda is followed by five full pages of adulatory depictions of the National Socialist leader. Across the city, jaws must have dropped and coffee cups spilled. Decades later, these jarring images remain highly provocative and continue to prompt questions. Why would $P M$, a vehemently anti-fascist publication, reproduce photographs which, at least upon first glance, seem to promote a benevolent image of the Nazi leader at that crucial historic moment? What was the nature of the contemporary discourse around propaganda at the time of this editorial decision?

This article takes those questions as points of departure in examining $P M$ s reproduction of Axis propaganda photographs in 1940 and 1941.3 I will argue that PMs editors and its photography critic of the time, Ralph Steiner, reflecting an acute awareness of contemporary strategies of propaganda (particularly photographic propaganda), presented images such as the one described above in the early 1940s as part of an innovative campaign of counter-propaganda. In effect, they attempted to inoculate their US readership against the effects of National Socialist and Italian Fascist propaganda by reproducing the very images at the heart of their protest, but with their original intent defused by captions and accompanying texts that draw attention to photographic artifice and contextual manipulation. Here, for example, after the images' initial shock, readers would have registered the line "How Hitler Deceives his PeopleA Picture Analysis." This title, appearing on the first page, frames that initial image and the following photographs as examples of covert deception. At the same time, in offering up $P M$ as a reliable guide through the maze of truth and falsity in war photographs, $P M$ s editors deployed this picture essay as evidence of their own credibility and in so doing added another layer of persuasion. ${ }^{4}$

PMs treatment of these and other Axis propaganda images stands as a remarkable episode in photographic and journalistic history during the Second World War. 5 It attests to the potency both of the photograph as a form of representation in the mass 


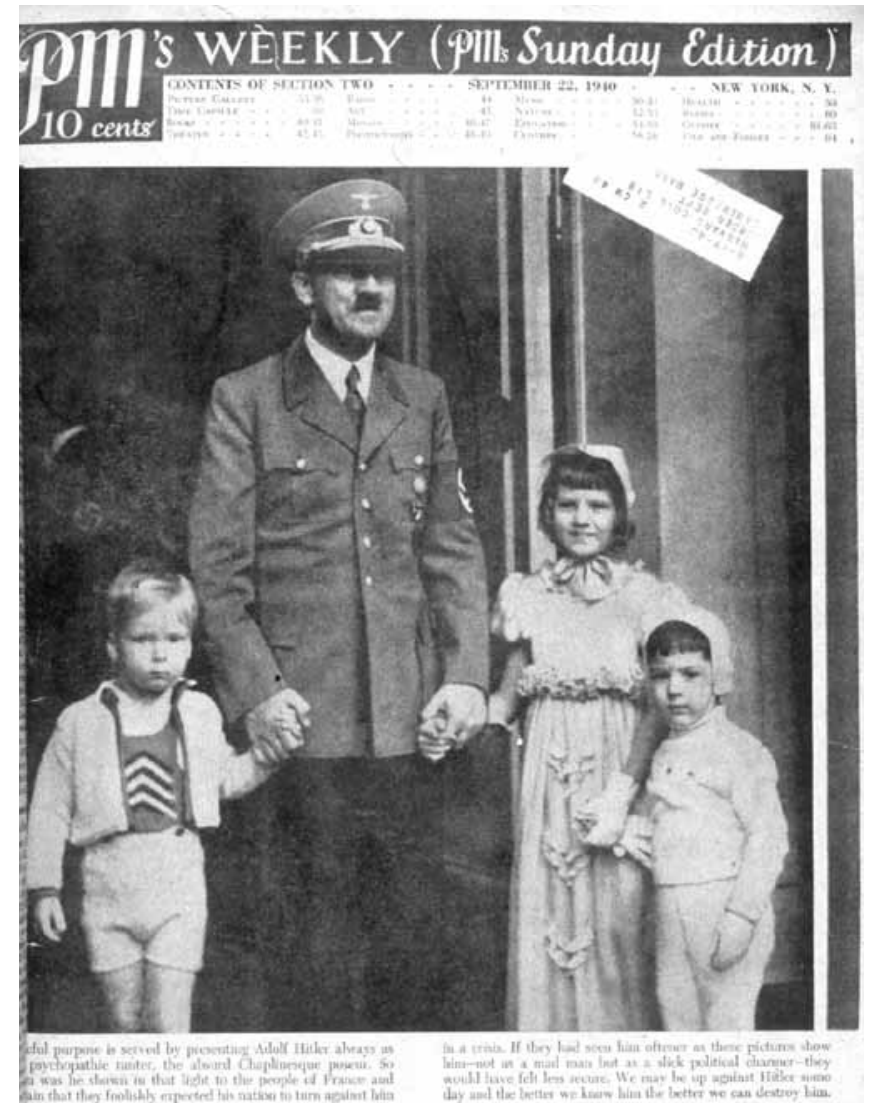

How Hitler Deceives His People-A Picture Analysis

Figure I. "How Hitler Deceives His People-A Picture Analysis," PM's Weekly (22 September 1940): 33. Nieman Foundation,

Harvard University.

media and of the concept of propaganda at the time. Indeed, propaganda, which was then broadly understood, according to J. Michael Sproule, as "a sometimes popular but always covert and institutionally promoted threat to intelligent public opinion," had become a somewhat obsessive concern. ${ }^{6}$ My analysis of these semiotically loaded images and their editorial presentation draws on the historical context of this influential newspaper and on contemporary perceptions of propaganda, as well as on classic and recent theorizations of the news photograph, and closes with a consideration of their horrific corollary: photographs of Nazi concentration camps published in 1945.

The questions posed in this essay are underscored by another constellation of issues revolving around the ethics of representation. How can images that not only depict fascist figures but embody fascism in their very form be discussed-much less reprinted-without, however inadvertently, reproducing their ideological message or, in an equally troubling turn, trivializing evil? At the core of PMs strategy in reprinting and critiquing fascist propaganda photographs were the principles that, first, re-contextualization and critical reception are powerful means of resistance, and secondly, that eschewing direct reference to the representation of evil may have grave consequences. While PMs strategy may have been flawed, those principles also form a guide for the discussion that follows.

\section{"We are against fraud and deceit"}

Ralph Ingersoll, a protégé of publishing magnate Henry Luce, launched $P M$ on 18 June 1940 with financial backing from Chicago department store tycoon Marshall Field III. Ingersoll served as PM's editor for most of the newspaper's history. He was not only the former publisher of Luce's flagship journal Time but also the developer of the influential formats of both Fortune and Life magazines. ${ }^{7}$ Ingersoll envisioned $P M$ as a reform of the daily newspaper, employing some of the devices characteristic to Time Inc. magazines, including the division of news into departments and the prominent use of photographs to relay information on current events. Despite his long affiliation with Luce, that vocal proponent of free enterprise, Ingersoll was more attuned to the leftist, pro-union politics of the contemporary Popular Front. ${ }^{8}$

$P M$ quickly gained a reputation as a liberal alternative to New York's other dailies. In drafts of a now well-known prospectus for the publication, Ingersoll set the nationalist and progressive tone for $P M$ as a whole.

\section{We are against people who push other people around, just for the fun of pushing, whether they flourish in this country or abroad.... We are against fraud and deceit and greed and cruelty and we will seek to expose their practitioners. We are for people who are kindly and courageous and honest. We respect intelligence, sound accomplishment, open-minded- ness, religious tolerance. 9}

Indeed, throughout its brief eight-year history, $P M$ emerged as a leading progressive voice in New York and a counterpoint to what Chris Vials has termed Luce's "imperial, capitalist formula." 10 To this end, Ingersoll gathered together an impressive staff representing a broad spectrum of leftist and moderate-left thinking in the United States. Among its staff members and contributors were the writers Lillian Hellman and Dashiell Hammett, the pediatrician Dr. Benjamin Spock, the artist Reginald Marsh, and the political caricaturist Theodore Geisel (better known today as Dr. Seuss). The paper became known for its pro-union rhetoric, its unflagging support of Roosevelt's various New Deal programs, and its resolutely anti-fascist position reflecting the values of the Popular Front, an alliance of leftist and liberal groups aimed to combat fascism. ${ }^{11} P M$ alerted 
US readers to Nazi anti-Semitism when most other papers considered reports of atrocities and persecution visited on European Jews as mere hearsay, and opposed isolationism at a time when most Americans were still conflicted about the war. ${ }^{12}$ Finally, $P M$ solidified its progressive position by carrying no advertising. ${ }^{13}$ In this, Ingersoll played on a growing popular cynicism concerning mass publications' relationship to advertising and on the corollary belief that omitting advertisements was a guarantor of journalistic objectivity.

To "write stories in photographs"

PMs chief innovation, other than its progressive stance, was its use of news photographs, which distinguished it dramatically from its competitor newspapers. ${ }^{14}$ While the incorporation of photography had increased across the international daily press in the years leading up to the Second World War, ${ }^{15}$ print journalists' attitudes toward the medium were conflicted. ${ }^{16}$ Photographs were often treated as mere illustrations or visual evidence to support the central task of textual narration even as they had become important in authenticating news stories' claims. By the beginning of the Second World War, most newspapers had resigned themselves to the use of photographs, although as decidedly secondary material. ${ }^{17}$ Nonetheless, photography became a characteristic feature of war coverage, if one that was highly censored. According to Barbie Zelizer, "World War II was documented by more photographers than any previous military conflict," with advancements in wire transmissions enabling audiences at home to experience war in a more visceral and immediate way than had earlier generations. ${ }^{18}$

PM included more photographic images than most of its competitors and unapologetically promoted the photograph as a carrier of news information. Its editors appeared to disdain New York tabloids' exploitation of sensationalist images, suggesting that their own use of the medium would be more measured and authoritative. ${ }^{19}$ In this way, $P M$ diminished the hierarchies of text and image that were a norm in the press of the time. As the person who oversaw Life magazine's unequivocal embrace of photojournalism, Ingersoll was uniquely suited to instituting a prominent role for photography in a daily newspaper. ${ }^{20}$ Ingersoll proposed that photography was "not simply an important but a vital and integral part of the very idea of $P M$...[which would] write stories in photographs as reporters wrote them in words." $21 \mathrm{He}$ committed the newspaper to publishing at least five full pages of photographs in addition to images illustrating articles in each weekday issue. To this end, Ingersoll and William T. McCleery, the paper's picture editor, recruited some of the most acclaimed photojournalists of the day, including Weegee (Arthur Fellig) and Margaret Bourke-White. ${ }^{22}$

\section{PM's Weekly}

Ingersoll and McCleery came closest to fulfilling their commitment to the innovative use of photography in PM's Weekly, the Sunday supplement, which McCleery also edited. ${ }^{23}$ Following the "hard news" in the paper's main section, PM's Weekly carried what Ingersoll termed "news for living:" bargains for consumers, articles for children, and advice for pet owners were interspersed with arts reports and personal accounts of the war. ${ }^{24}$ Out of its usual thirty-six pages, at least nine were devoted exclusively to photography, with additional photographic reproductions included in other sections. The magazine opened each week with "PMs Picture Gallery," a six- or seven-page photo-story featuring a single image on each page that set the tone for the section.

Beginning on 18 July 1940 and for the following two years, PM's Weekly also published one of the first weekly columns of photographic criticism in the daily press. It was written by $P M$ s photography critic Ralph Steiner, a well-known figure in the New York art scene since the 1920s and a photographer and filmmaker in his own right. ${ }^{25}$ Steiner offered instruction to amateur snapshooters and promoted the work of socially engaged professional photographers. ${ }^{26} \mathrm{He}$ used his column to challenge generally held assumptions about the news photograph's claims to directness, lack of mediation, and objectivity - what Roland Barthes famously termed its "denoted message," that is, its seeming existence as a "perfect analogon of reality.... message without a code." 27 For many readers of the popular press in the early 1940s, news images seemed to offer an unmediated encounter with events occurring around the world. The urgency of the current international conflict as well as a yearning for direct experience at a time when the public was largely skeptical of abstract statements from governments and other authorities rendered audiences particularly susceptible to the photograph's presumed denotative character. ${ }^{28}$

Indeed, the analog photograph's denoted message has been and remains so compelling to viewers that it is often designated as ontological. W.J.T. Mitchell argues that connotation-or contextual mediation-in effect is actually based on photographic denotation:

$[\mathrm{O}]$ ne connotation always present in the photograph is that it is a pure denotation; that is simply what it means to recognize it as a photograph rather than some other sort of image. Conversely, the denotation of a photograph, what we take it to represent, is never free from what we take it to mean. ${ }^{29}$

In the face of photography's compelling claims to a denotative status, Ralph Steiner undertook something of a visual literacy campaign in his PM's Weekly columns. By exposing photographic mediations, Steiner underscored the photographer's creative and technical skill while purportedly subverting the 


\section{What Is Truth in Photography?}

The camera cannot lie" That cliche $k$ a lir itself, because every camera lies Eved when a photographic portrait tells the truth in all the above categories Bles is in the hands of an expert eraftsman with a passion for the truth. On it can tell only a small portion of the truth. it can be a true pictore of is man

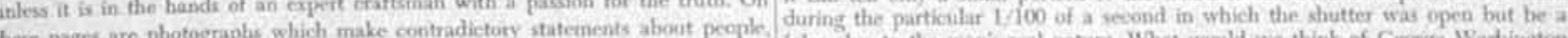
What wanld we think of Cecrise Wastiniton 0 some of these pictures must be wrong.
if the ooly picture record we had was a photograph taken when he blimked? (See The camera records shape, color, trae and form. It is foolpmof only in its Sinister ou page 49.

ecording of shape. It usually lies about the others. For intaince: before the days the camera carnot lie" is true only in the sense that it is a little harder to f panchumatic film ned hair "came out" too dark-now it registers too light. Tone tell a monplete falshood with w camera than with words, The thing to bear in

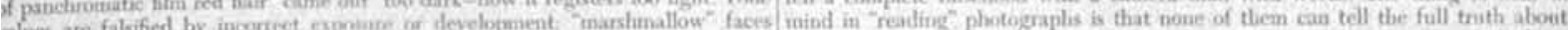

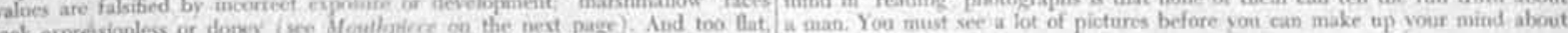
hadowless lighting distarts a faceiv form

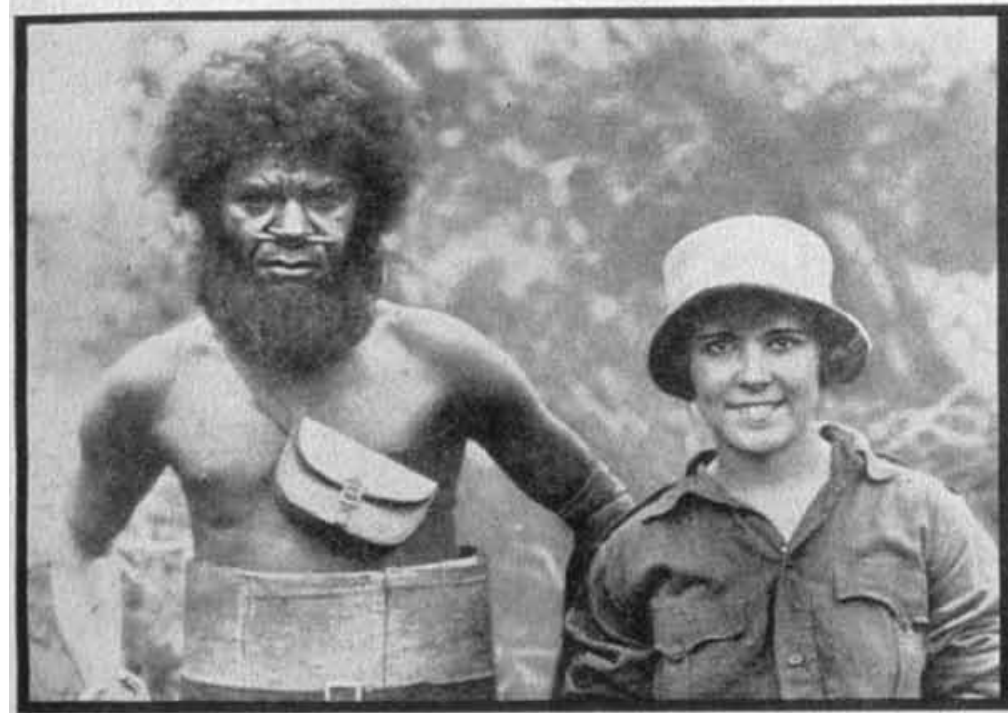

Huntress Hete is Mrs. Martin Johnson in 1912, in the dins when she was making movic with her busbaod in Africa. It is a-straight-forkard photograph without pretty hamer, sho was able to withatand the hardahips and dangen of a safari.

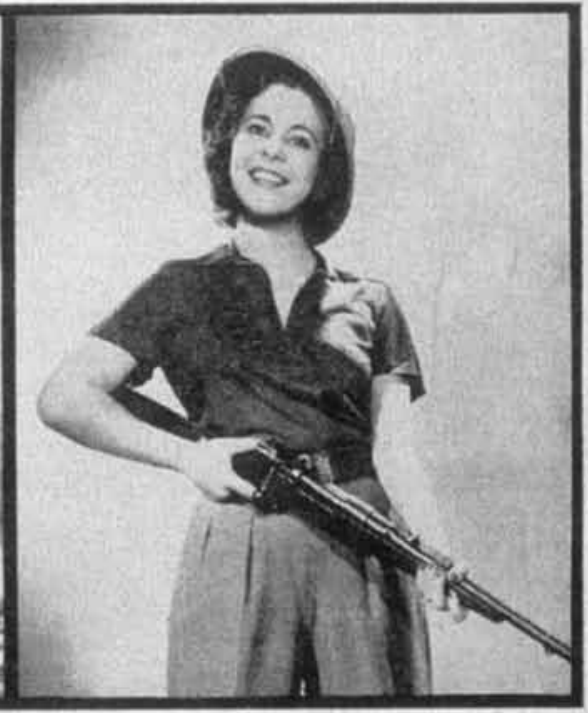

Peacherino This is Faramounts version of She looks like a kittrnish sombinomore at Holhwood High who coulda't lot the vide of a barn door at forty paces.

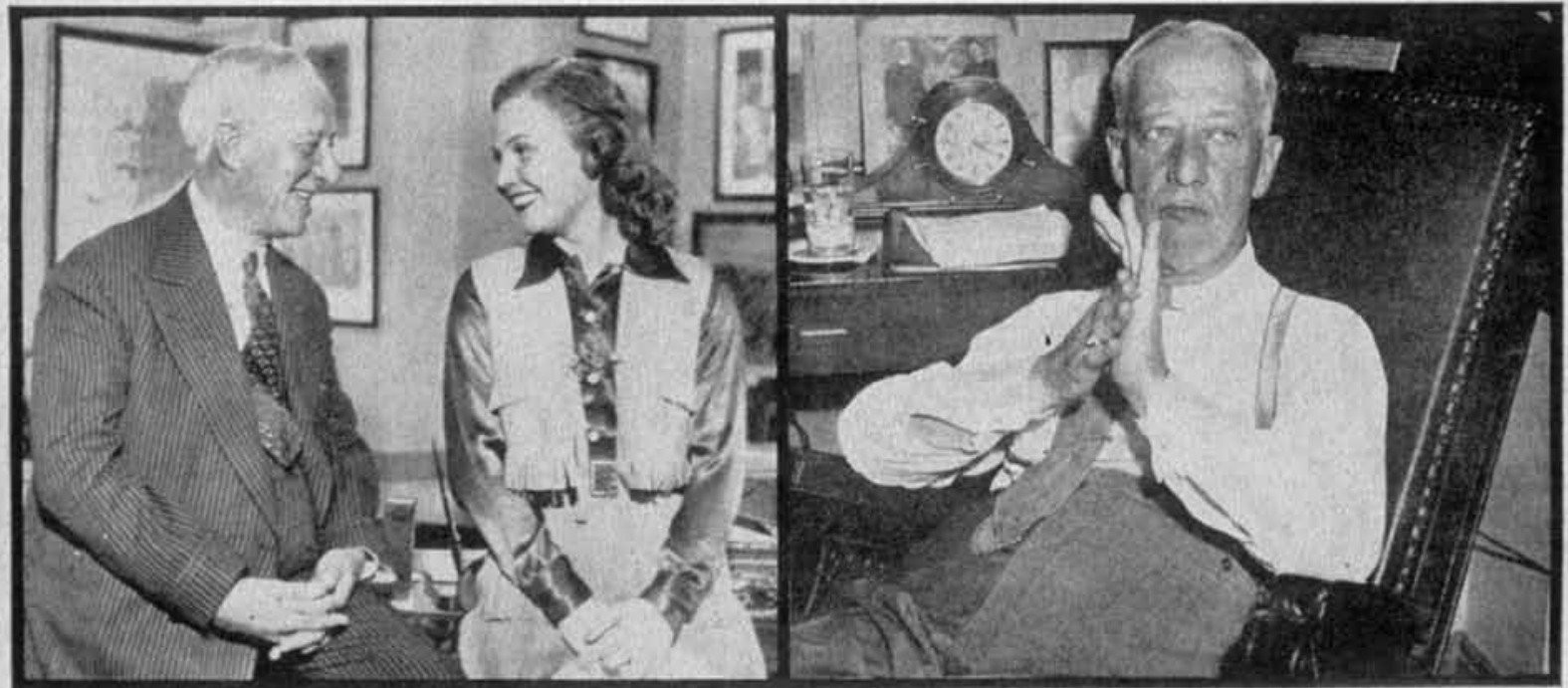

Nice Guy This is the At Smith of the brown derby and the sidewalks

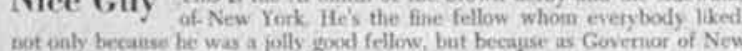
Yotk he was a progressive, socially minded champios of the poor
Bad Loser. This is the picture of a man whose diay is over, who sir torial arnechair, acquires a bay window, and has the expression of a ditappointed presidential candidate who berame reactionary.
MORE:

Figure 2. Ralph Steiner, "What is Truth in Photography?" PM's Weekly (2 February 194I): 47. Nieman Foundation, Harvard University. 
persuasive potential of the photographic representation. He became increasingly preoccupied by the question of photography's presumed truthfulness. Largely, his columns address the mediating effect of connotative devices and specifically what Barthes later termed "photogenia" in reference to the photographer's and editor's arsenal of technical tools including lighting, exposures, and effects achieved in the darkroom. ${ }^{30}$ In a 4 August 1940 column, for instance, Steiner compares photographs cropped in different ways in order to demonstrate that seemingly cosmetic or insignificant cropping can significantly alter an image's meaning. 31

Other columns address the question of the photograph's presumed denotative status more directly. In "What is Truth in Photography?" (fig. 2), the bluntly titled 2 February 1941 column, Steiner debunks perceptions of the photograph as a "perfect analogon of reality." 32 Here he pairs press images of well known personalities of the day, each supposedly revealing a different facet of the same individual. 33 In a photograph at the bottom left of the layout, New York State Governor Al Smith smiles fondly while engaged in conversation. The caption identifies him as a "Nice Guy." In a second portrait, Smith glares at the camera while awkwardly fidgeting with his hands and becomes, according to the accompanying caption, a "Bad Loser... a man whose day is over." Steiner's language and his choice of illustrations are mockingly simple, yet they demonstrate how, as Barthes later described, "connotation is produced by a modification of the reality itself" - through props and pose. ${ }^{34}$ At the same time, Steiner uses text and captions as further mediating devices to direct viewers toward a suggested interpretation. In so doing, he emphasizes the role of reception in the formation (and negotiation) of photographic meaning, warning his readers that the familiar claim that

\footnotetext{
"the camera cannot lie" is true only in the sense that it is a little harder to tell a complete falsehood with a camera than with words. The thing to bear in mind in "reading" photographs is that none of them can tell the full truth. 35
}

Such statements were novel at a time when news publications were more typically invested in promoting the photograph as a purely denotative form of representation.

"In a sense, every photograph is a piece of propaganda"

Steiner's interest in defusing perceptions of photographic truth may have been motivated by the question of propaganda, which since the late 1930s had permeated US culture and emerged as a particular source of apprehension among progressives. 36 Writing in a 1939 issue of The Nation, the popular commentator and later $P M$ staff member Max Lerner ironically termed the period "a new Golden Age of Propaganda." 37 Figures ranging from
John Dewey to Walter Lippmann addressed the subject. The most influential scholarly text was Harold D. Lasswell's treatise on WWI, Propaganda Technique in the World War, which characterized propaganda as maximizing power with minimal material expense. 38 The US public in general had become wary of the persuasive manipulation that appeared in advertising and in reporting domestic politics and the conflict overseas. ${ }^{39} \mathrm{PM}$ s own decision to omit advertising both reflected and exploited the popular distrust of one of the period's most pervasive-if relatively benign - forms of propaganda.

The most influential contemporary US body to explore the concept was the Institute of Propaganda Analysis (IPA), which included such prominent progressive thinkers as the sociologist Robert S. Lynd, the journalist I.F. Stone, the historian Charles A. Beard, and the educators Clyde Miller and Ernest Johnson. ${ }^{40}$ In existence from 1937 to 1942, the IPA was, in effect, a lobby group publishing anti-propaganda critiques. It defined propaganda broadly as the "expression of opinion or action by individuals or groups deliberately designed to influence opinions or actions of other individuals or groups with reference to predetermined ends." 41 The IPA mounted analyses of diverse forms of persuasion emanating from politics, the advertising industry, and religion, discrediting all types of persuasion uniformly.

But the IPA's blanket condemnation of propaganda no longer seemed appropriate and effective to many Americans in the early 1940s, when the threat of fascism was urgent. Instead, the US government and media-including Hollywood and many news agencies - adopted a relativist position, accepting propaganda as a useful means of building morale while simultaneously reviling its fascist applications. In the months leading up to US participation in the Second World War, US journalists, including photojournalists, generally saw themselves as offering support to the Allied cause. ${ }^{42}$ They, therefore, accepted the usefulness of pro-Allied propaganda in bolstering domestic morale and education programs, while simultaneously making efforts to expose Axis propaganda. PM, for example, discussed propaganda specifically in terms of the threat it posed to security and morale.

The IPA responded to this shift in public sentiment and media approach by turning its own attention increasingly to war-related propaganda. In 1940, it published War Propaganda and the United States, a book that exposes and examines propaganda emanating from Allied, Axis, and domestic sources. 43 Notably, its authors Harold Lavine and James Wechsler were both PM staff members: Lavine was the paper's assistant managing editor during the early 1940s and Wechsler was its labour editor. ${ }^{44}$ In this book, as in their work at $P M$, they were explicit about their loyalty to the Allied cause and about their heightened concern over Nazi propaganda as "an integral part 


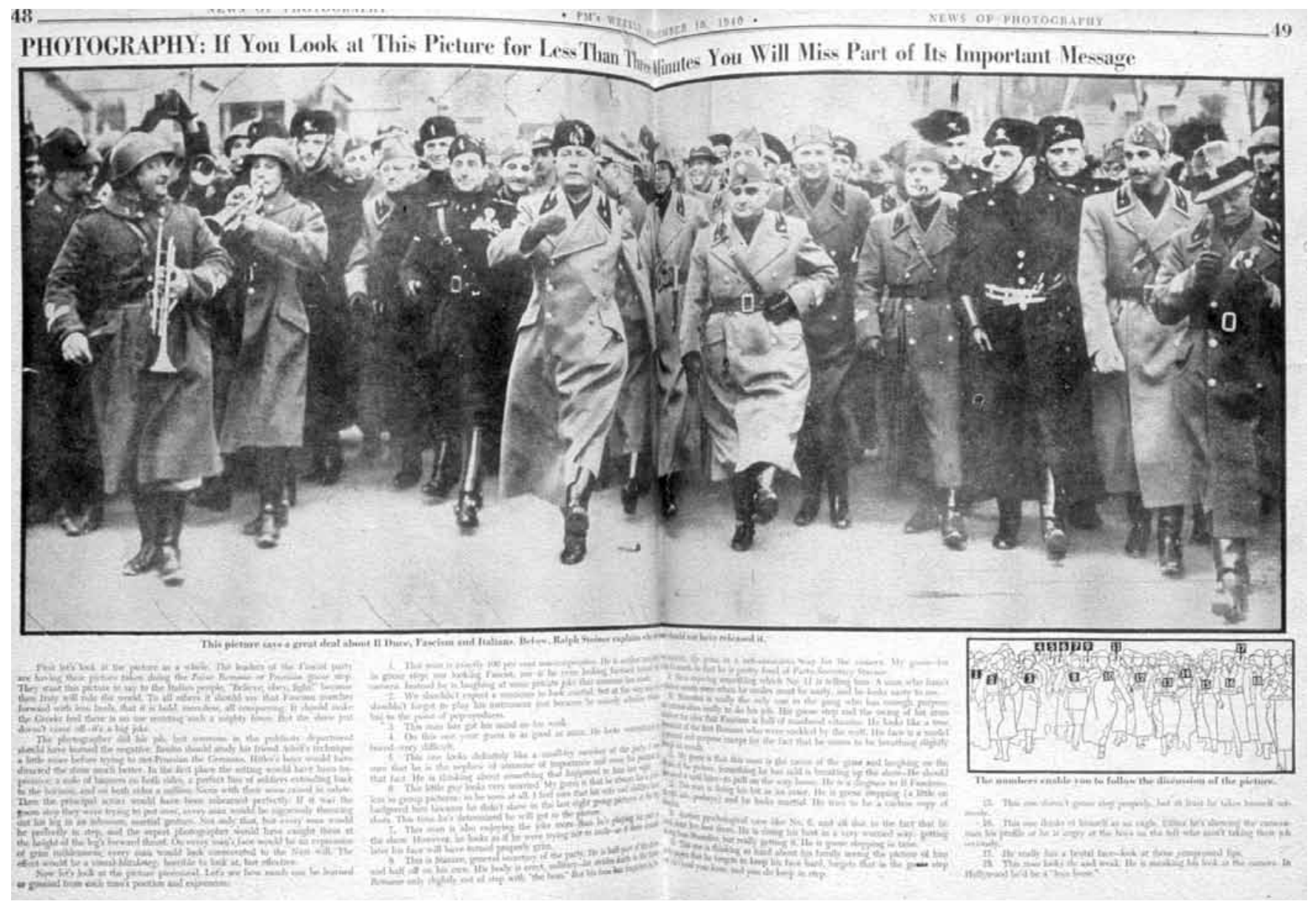

Figure 3. Ralph Steiner, "If You Look at This Picture for Less Than Three Minutes You Will Miss Part of Its Important Message," PM's Weekly (I0 November 1940): 48-49. Nieman Foundation, Harvard University.

of Germany's war machine." ${ }^{5} P M$ was acutely aware that both the Allied and Axis camps used propaganda as a psychological tool in warfare. By the spring of 1941, the paper had unambiguously launched an anti-isolationist campaign, which included a series entitled "Well, What are We Going to Do About It?" as well as articles and pictorials on Nazi persecution of Jews and other groups.

At PM's Weekly, it was the potency of war propaganda photographs that particularly concerned Steiner and the editorial staff. In a 24 November 1940 column, Steiner offers a prescription for the effective use of photographic propaganda in support of the United Kingdom. 46 Entitled "Some Photographers Make England Look Like This... But Sensitive, Sensible Photographers Make England Look Like This," the column compares different depictions of the British home front. Here Steiner uses some of the same techniques for exposing connotative procedures as he had in columns unrelated to the war, including image comparisons and text to direct the viewer toward a prescribed reading. The opening page features Britons at play, while the following two-page spread depicts them defending their country and living under the modest and gritty conditions of wartime England. Steiner urges photographers to use mediation effectively in order to gain internationalspecifically US - sympathy, recommending that they not depict overly cheerful people but highlight instead the industriousness of Britons in a time of peril. In the same column, Steiner articulates his own relativist position:

In a sense every photograph is a piece of propaganda.... [W] hen a nation at war asks for our help, the pictures it uses to get across its message are very important. By looking at the pictures on these pages - by seeing what is true and false in war propaganda pictures, readers can sharpen their sense of truth about all photographs. 47 
For Steiner, all photographs are vehicles of persuasion. It remains for the reader/viewer-at the point of reception-to learn to discriminate between "what is true and false."

Referring explicitly to Axis representations, Steiner cautions in his characteristically vivid prose that, "today we see a lot of a...kind of propaganda photographs - one which has behind it the photographic facilities and talent of an entire nation, and the object of which is to scare hell out of the whole world." 48 Indeed, by the early 1940s, US anxiety over propaganda was specifically directed at Axis campaigns of persuasion. The critique of fascism by Max Horkheimer and other members of the Frankfurt School, some of whom were in exile in the United States after their expulsion from Germany in 1933, attuned many US thinkers to the threat of Nazi propaganda specifically. Horkheimer's examination of fascism in terms of "psychosocial mechanisms of obedience"-the use of rhetoric and media, among other means, to render a populace compliant with Nazi goals-provided American audiences with a language with which to address Axis textual and pictorial campaigns. ${ }^{49}$ And the need to address them was deemed urgent. As the sociologist Edgar Dale declared in 1940, "to combat Fascism we must... teach the common man to detect and analyze propaganda." 50

Steiner and PM's Weekly took up that call in making the remarkable editorial decision to publish numerous examples of Axis photographic propaganda. During the twelve-month period from July 1940 to July 1941, PM's Weekly reproduced approximately twenty-five full pages of official Nazi and Italian Fascist photographs. During the same period, the New York Times and the New York Herald Tribune ran substantially fewer examples of such images. ${ }^{51}$

Examples of Axis propaganda were not unknown outside of $P M$ at this time in the United States. Images and textsfrom both sides of the conflict-were disseminated within the country and circulated to enemy states in attempts to destabilize morale and foster sympathy. According to Deborah Lipstadt, from 1933 until 1939, the German government employed US public relations firms in order to facilitate positive coverage in the US press and, until as late as 1942, maintained a policy of currying favour with US correspondents in Germany. 52 But often these campaigns were directed at what we might term today "target audiences." For example, nationalistic material was targeted specifically toward Americans of German descent, and anti-Semitic literature, toward such groups as the Ku Klux Klan and the Christian Front. Before the Pearl Harbor attacks, Nazi propagandists also addressed isolationist groups. 53 Indeed, as Lipstadt argues, "the main spying and propaganda activities that took place in America were...through isolationist circles. Isolationists were better equipped to achieve German objectives of keeping America out of the war than were any of the pro-Nazi groups in the United States." 54
Steiner and the editors of PM's Weekly attempted to subvert the original intent of Axis images through many of the same techniques employed in the critic's columns about more benign subjects. With Axis propaganda photographs, Steiner discards the technique of image juxtaposition. He uses the column's layout to highlight connotation, superimposing images with diagrams, for instance, to effectively distance the reader from the images' intended message. But it is in captions and accompanying text that Steiner's campaign of destabilizing Axis images is most fully articulated. Notably, his commentaries operate both as analyses of connotation and as additional layers of connotation. They draw attention to those procedures within the reproduced images that "modify the reality" - trick effects, poses, and objects or props-and to photogenic effects such as lighting and cropping. At the same time, the PM captions and texts insert other forms of connotation by directing viewers toward specific pictorial details, imposing alternate readings of the images, and deflating the images' original intent through irreverent humour. In this, the paper's editors recognized Barthes's later contention that - contrary to convention-text illustrates image. Captions and headlines effectively direct the viewer toward a specific, prescribed reading of the image, "anchoring" the image to that interpretation, while sequential layouts employ "relay" to frame the image within a broader conceptualized narrative arch. 55

The process of imposing new meanings on the images was further aided by the removal of the original contextual information. Identifications of photographers, of specific locations, and of most of the people depicted, were-in contrast to Steiner's more quotidian columns-consistently omitted. Through these omissions, the images become typologies, standing for fascism as a whole. This tendency to omit or diminish personalizing identifications was consistent with the way such images were probably circulated initially by the fascist propaganda machines: decontextualization, because it erases alternative modes of thought in favour of dominant ideology, is a hallmark of visual persuasion. Yet, since they lack specificity, these images remain paradoxically more malleable to other interpretations and meanings. 56

In a column on Axis propaganda dating from 10 November 1940, Steiner takes a view of Mussolini and his generals marching in goose-step as raw material for a lesson in visual propaganda (fig. 3). This column reproduces, across a full two-page spread, an unidentified image of the Italian Fascist leader walking toward the camera while heading a parade of dozens of military figures. The column layout distances the reader from the image's original message by surrounding it with prominent contextual information. At the lower right, a diagram added to elucidate the photograph identifies most of the figures. The use of this diagram $-\mathrm{a}$ familiar editorial addendum to group 


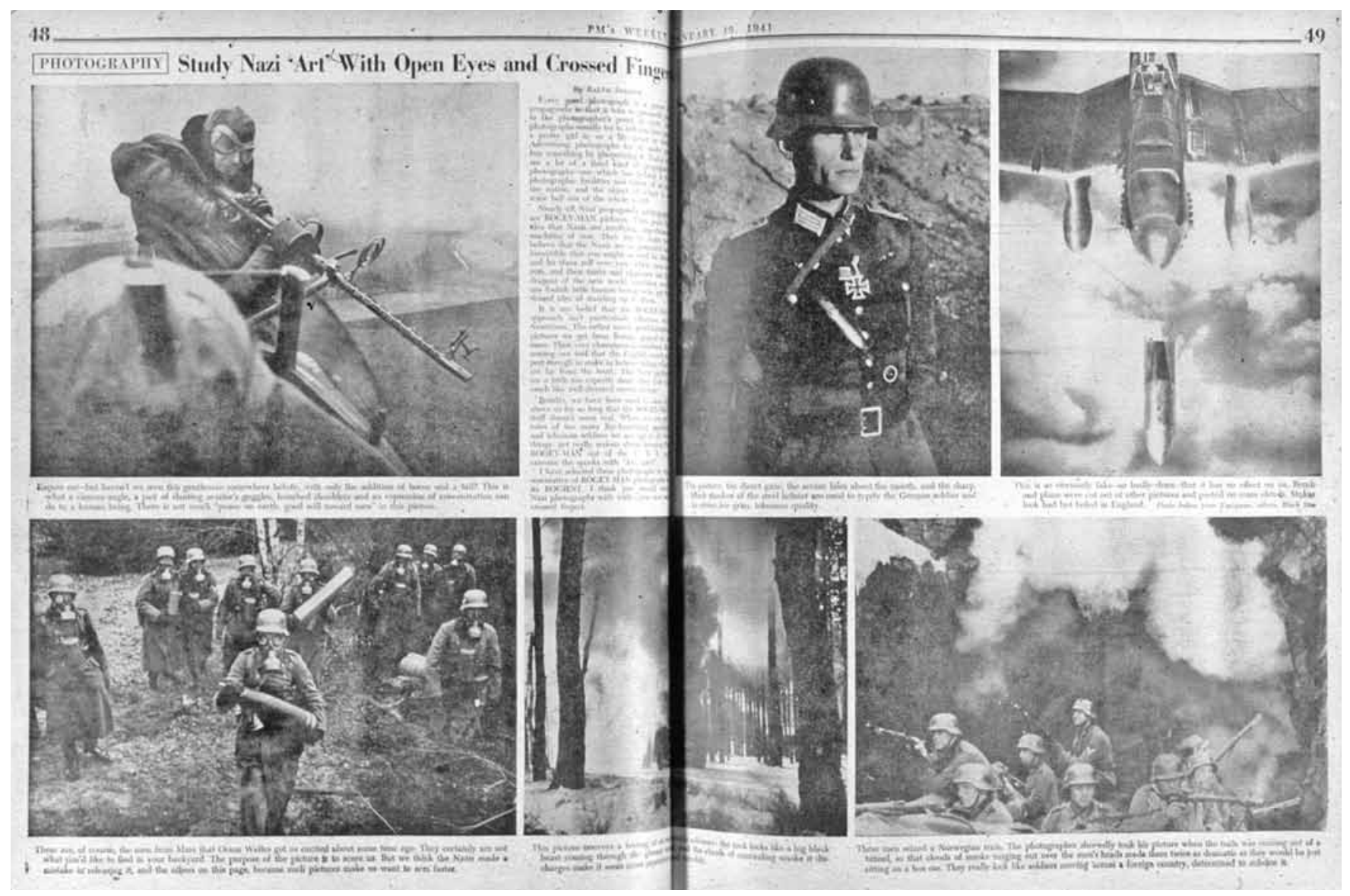

Figure 4. Ralph Steiner, "Study Nazi 'Art' with Open Eyes and Crossed Fingers," PM's Weekly (19 January 194I): 48-49. Nieman Foundation, Harvard University.

portraits-denaturalizes the photograph; it stops the viewer from being swept into the movement of the scene and experiencing that seemingly direct encounter promised by the photograph's presumed denotative status, and implicitly encourages viewers to read the image as the depiction of a group of social actors. The image is also sandwiched between Steiner's commentary below and a prominent headline above that reads, "If You Look at This Picture for Less than Three Minutes You Will Miss Part of Its Important Message." The headline succinctly directs the viewer toward representational strategies. Steiner's accompanying text draws attention to pose and props in the image, not as examples of shrewd manipulation, but as failed attempts at pictorial coercion. Noting the image's visual chaos, Steiner offers the following "advice:"

Someone should have burned the negative.... Benito should study his friend Adolf's technique.... Hitler's boys would have directed the show much better. In the first place the setting would have been impressive; a mile of banners on both sides, a perfect line of soldiers extending back to the horizon, and on both sides a million Nazis with their arms raised in salute. Then the principal actors would have been rehearsed perfectly. 57

When Steiner turns to the work of "Hitler's boys" themselves, his tone changes to one of genuine apprehension. In his 19 January 1941 column (fig. 4), for example, he advises the reader to "Study Nazi 'Art' with Open Eyes and Crossed Fingers" and presents a two-page layout of six unidentified Nazi images of German soldiers and war machinery. One photograph features a Nazi officer gazing thoughtfully at the distance while four others show German soldiers on the battlefield. The final image is a photomontage representing a German plane dropping bombs. By including so many images together and in small scale, Steiner exposes them as works of pure artifice and profoundly diminishes the probable intended effect of intimidation. The title, "Study Nazi 'Art' with Open Eyes and Crossed 


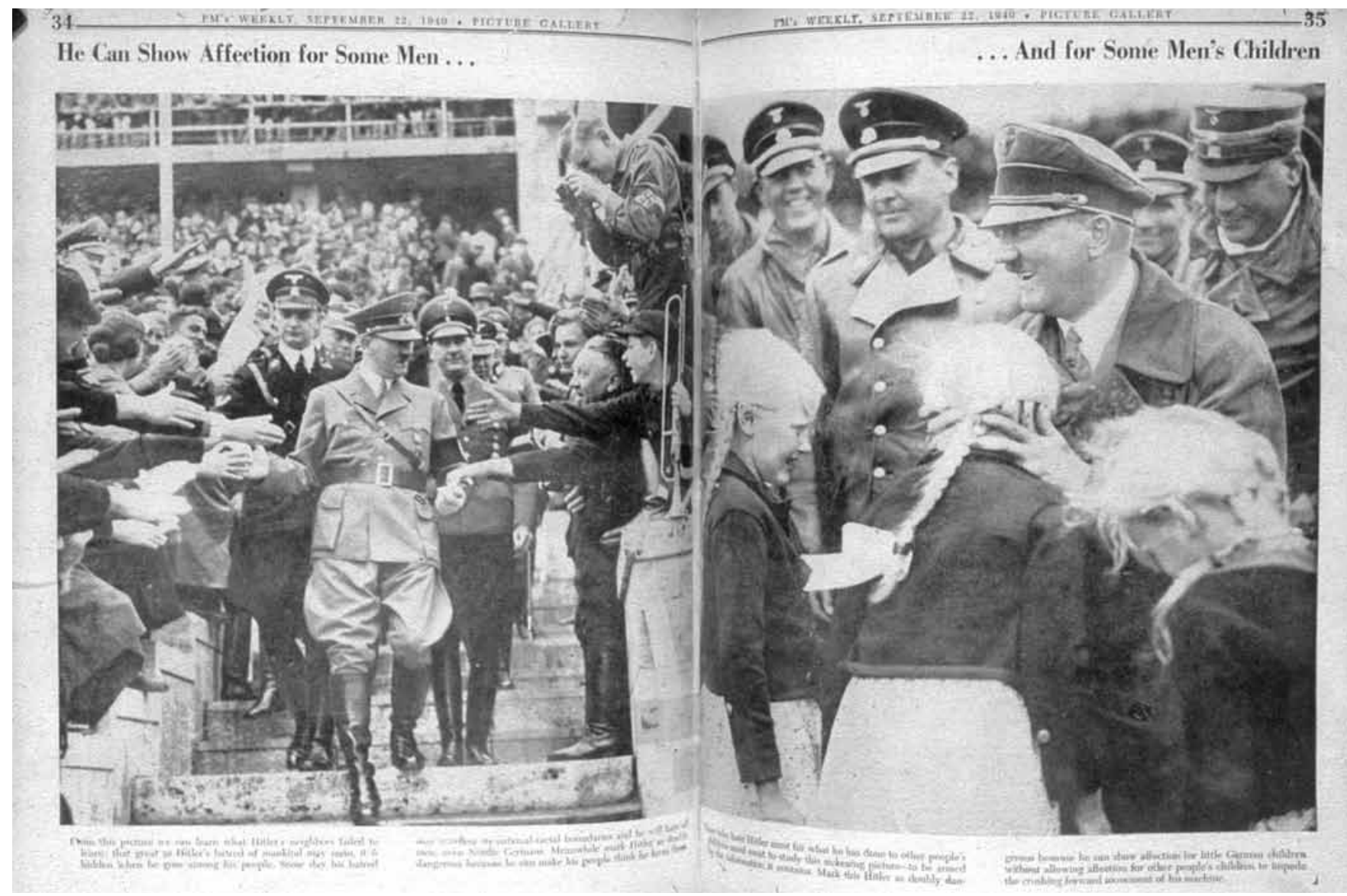

Figure 5. "How Hitler Deceives His People—A Picture Analysis," PM's Weekly (22 September 1940): 34-35. Nieman Foundation, Harvard University.

Fingers," again signals that the key concerns here are representation and reception. In his text, Steiner defuses each image. The seeming ferocity of a gunman at the upper left, he suggests, was accomplished only by "a camera-angle, a pair of slanting aviator's goggles, hunched shoulders and an expression of concentration." The various depictions of soldiers are dismissed as mere characters from Orson Welles's radio adaptation of War of the Worlds. 58 Finally, Steiner suggests that the crudely constructed photomontage is all but laughable: "This is so obviously fakeso badly done-that it has no effect on us. Bomb and plane were cut out of other pictures and pasted on some clouds."59 Here Steiner's dismissal seems to belie his own anxiety.

In both columns cited above, Steiner privileges reception as a site for the formation of meaning. He encourages readers to develop skills of visual literacy and critical viewing (through attentiveness and awareness of connotative procedures) in order to immunize themselves against the images' original intents (intimidation, in most cases). Decoding would then effectively defuse these psychosocial weapons. Thus Steiner attempts to situate the reader within what Stuart Hall terms an "oppositional ideological perspective," one that rejects the dominant code suggested by the photograph-fascism. ${ }^{60}$ At the same time, Steiner replaces it with another code, that of $P M$ as a reliable conveyor of fact.

PM's Weekly's most dramatic subversion of Axis images was the 22 September 1940 photo-essay with which this article began. "How Hitler Deceives His People-A Picture Analysis" (fig. 1) ${ }^{61}$ consists of six full-page photographs, all featuring the Nazi leader. The photographer or photographers are unidentified, as are all of the figures depicted except Hitler himself.62 In sequence, the photographs portray Hitler surrounded by three children; walking through a throng of supporters; greeted by a group of girls while surrounded by military figures (fig. 5); saluting a crowd; listening to Julius Streicher, publisher of the party newspaper Der Sturm; and, lastly, at a podium addressing an unseen crowd. 
These photographs, standard pieces of Nazi party propaganda taken probably between 1933 and 1938, project an image of Hitler as a revered, good-natured man, at home among his people even while he rises above them. They echo those featured in the 1932 picture book The Hitler No One Knows and the 1933 Nazi party publication, Deutschland erwacht: Werden, Kampf und Sieg der N.S.D.A.P., in which Hitler is also shown surrounded by affectionate children and young girls. ${ }^{63}$ These images were most likely intended for German audiences rather than as part of a foreign propaganda campaign. They typify what Jacques Ellul has characterized as a "propaganda of integration," one that seeks "total adherence to a society's truths and behavioral patterns," in this case by naturalizing and familiarizing fascist authority. ${ }^{64}$ These images' compositional celebration of control, submission, grotesque idealization, and racial homogeneity betray them as fascist not merely in subject matter but in pictorial rhetoric. They are prime examples of what Susan Sontag has memorably termed a "fascist aesthetic." 65

Unlike Steiner's columns, this PM's Weekly photo-essay offers no visual modification of the images: they are presented alone, each filling a full page and without visual addenda. But titles, appearing in bold at the bottom of the opening page and at the tops of the following five pages, alert the reader to their trickery. Following the cover, "How Hitler Deceives His People-A Picture Analysis," titles on subsequent pages read, "He Can Show Affection For Some Men...," "...And For Some Men's Children...," "...He Can Wear A Look Of Dignity...," "...And Stop Raving When He Wants To," and the pictorial essay's final page, which depicts Hitler standing at a lectern, is headed by the title, "He Can Use the Words of Honest Men." This photo-essay attempts to counter the then typical depiction (and dismissal) of Hitler in the US press as a madman. Instead, it suggests that the Nazi party has constructed an image of him as an admirable leader within Germany, and that it is precisely this convincing appearance that makes him a threat. Captions at the bottom of each page expand on this in repetitive refrains. In one, the reader is told,

His neighbors were fooled too long by Hitler's trick mustache, his hired-man's haircut, his old raincoat. They knew a man incapable of dignity could not long control a nation, and they thought Hitler incapable of dignity. Study this picture and mark Hitler doubly dangerous because he can feign dignity at home without tempering the indignities he commits upon other nations. 66

The emphasis is almost solely on how photographs contribute to managing a public persona. The editors emphasize, in effect, how pose and objects (or props) modify "reality itself." In so doing, they attack photogenic connotation less overtly than
Steiner did in many of his columns and treat the photographic image as an unproblematized denotative message.

Steiner's and PM's Weekly's presentation of enemy propaganda starkly contrasts with other, more frequently favoured, contemporary journalistic approaches. A July 1940 issue of London's Picture Post, for instance, includes an image of a saluting Hitler paired with the figure of Winston Churchill: one is presented as the very embodiment of totalitarianism and the other, of democracy. ${ }^{67}$ The impact of the Nazi photograph is thus diminished; it is relegated to the role of a mere counterpoint to a heralded British way of life. The radical press also used pictorial juxtaposition in illustrations of the Nazi leader. In The New Masses, William Gropper and other artist illustrators typically depict Hitler as a repressive demagogue seen in contrast to a unified working class. ${ }^{68}$ The manipulation of photographic images themselves was another prominent method of pictorial critique in the antifascist press. John Heartfield employs photomontage in Arbeiter Illustrierte Zeitung to critique Nazi figures and policies. In his famous Adolf the Superman: He Eats Gold and Spews Idiocies (1932), Heartfield combines a photograph of Hitler's face and torso with other elements, including a stream of coins and an X-ray, to present the Nazi leader as a money-eating automaton. ${ }^{69}$

In contrast, columns and photo-essays such as "How Hitler Deceives His People" maintain the integrity of the original photographs. Their captions alone modify these images, anchoring them to alternative and oppositional readings. By reproducing official Nazi and Fascist images unaltered and drawing attention to their pictorial artifice-that is, to connotative procedures-Ralph Steiner and $P M$ hoped to provide readers with critical tools for defusing such charged representations on their own.

PM's and Steiner's strategies for subverting fascist photographic propaganda hinged on the suggestion that meaning is formed at the point of reception. They reveal a fear that the authority of the photographic image would readily manipulate audiences, that readers would prove gullible to the sway of sophisticated visual campaigns. But at the same time, PMs strategy curiously presages relatively recent critiques of media consumption, particularly those challenging Theodor Adorno's assertion that the culture industry is an effect of the rise of a state monopoly capitalism that moulds a passive and malleable audience and thereby reduces the possibility of genuine resistance. ${ }^{70}$ Instead, by demonstrating in their sensationalist and irreverent texts that meaning is constructed at the point of reception, these critiques assume the active agency of the reader or audience. To offer readers tools to recognize photographic mediation is to provide a form of viable resistance, allowing the audience to occupy "an oppositional ideological perspective" on the original photographs. ${ }^{71}$ 
But counter-propaganda, too, is a discursive practice that both mediates "reality" and is capable of serving a propagandistic function itself. In suggesting that their paper held the key to exposing fascist imagery, what Steiner and the newspaper's editors undertook was also self-serving, convincingly positioning $P M$ as a trustworthy messenger of the "real" truth in that "New Golden Age of Propaganda."

\section{Epilogue: "Some limit had been reached..."}

The pictorials I have discussed in this article appeared as reports of fascist persecutions and atrocities were beginning to come to light in American news agencies. PM itself was a leader among the US press in exposing and publicly denouncing Nazi persecution as well as in criticizing the American government's inaction in the face of these horrors. ${ }^{72}$ In particular, the paper's foreign news editor, Alexander Uhl, became a tireless voice in this campaign. ${ }^{73}$ PMs denouncement of fascist persecution at times took a photographic turn. On Wednesday 5 February 1941, PM published a five-page pictorial on the Warsaw ghetto entitled "Inside Poland: Smuggled Pictures Show Nazi Persecution." 74 While this photo essay alerted US readers to some of the horrors occurring in Europe, it, like many press reports of the time, could not yet address the full breadth of contemporary Nazi atrocities. Indeed, according to Barbie Zelizer, Nazi atrocities were only "hinted at" in the Western press before the liberations in 1945. Detailed news reports about concentration camps, for example, were scant. Zelizer notes that these omissions resulted from a constellation of factors including reporters' basic misunderstanding of what was occurring, deep-seated Anti-Semitism in the press and US society broadly, and journalists' lack of access to concentration camps before 1945.75 Susan A. Brewer demonstrates that-partly in response to the public's skepticism over atrocity reports following the First World War-the Office of War Information decided to say little publicly about reports of Nazi atrocities. ${ }^{76}$

Photographs of the 1945 liberation of Nazi concentration camps that eventually appeared in the US press played a critical role in relaying the scope of these atrocities. ${ }^{77}$ Images made by photojournalists, military personnel, and others, of the unspeakable horrors witnessed in concentration camps finally jolted the world into acknowledging the depths of evil. Perhaps no one has more movingly articulated the galvanizing effect of these photographs than Susan Sontag in her well-known recollection of seeing photographs from Bergen Belsen in a Santa Monica bookstore:
Nothing I have seen-in photographs or in real life-ever cut me as sharply, deeply, instantaneously. Indeed it seems plausible to me to divide my life into two parts, before I saw those photographs (I was twelve) and after.... When I looked at those photographs, something broke. Some limit had been reached, and not only that of horror; I felt irrevocably grieved, wounded, but a part of my feelings started to tighten; something went dead; something is still crying. ${ }^{78}$

And, indeed, those images of atrocities have continued to cut generations of viewers sharply ever since. They provide evidence of what exceeds human belief.

Yet, the history of atrocity photographs is complex. The collective memory of the Holocaust has largely been rooted in photographic representations of camp liberations such as those encountered by Sontag. ${ }^{79}$ As Zelizer argues in Remembering to Forget, these images have been transformed over the ensuing decades from the referential to the symbolic, forming centrepieces of much memory work and, more recently (and paradoxically), pushing the realities of the Holocaust from memory. 80 They have, Zelizer contends, contributed to a distanciation from direct engagement with the reality of the Holocaust and other more recent atrocities. In fact, some writers, including the historian Susan A. Crane and Sontag herself in her last book Regarding the Pain of Others, have questioned the efficacy and ethics of continuing to display and view these images at all. ${ }^{81}$

War photographs make great demands of their viewers. They require alert readings of subtle visual codes and empathy for the human costs of conflict on a mass scale. Indeed, the very act of looking-or, alternatively, as Susan Crane has suggested, the act of "choosing not to look" - is always ethically loaded. As early as 1940 Ralph Steiner and the editors of $P M$ rejected the notion of a passive audience. Instead, they proposed that meaning is made, in part, at the point of reception and that therefore their readership could actively resist visual propaganda. Readers and viewers at that historic moment - as in our own-held an important ethical responsibility.

\section{Acknowledgements}

Thanks to Kim Sichel and Mitchell Frank for help with earlier versions of this article. For editorial guidance, I am grateful to Laura Brandon, Ersy Contogouris, Lora Senechal Carney, Annie Gérin, Dominic Marner, Catherine Harding, and the anonymous reviewer for $R A C A R$.

Due diligence has been made to locate the copyright holders of the images reproduced in this article. 
Notes

1 Ralph Steiner, "What is Truth in Photography?" PM's Weekly (2 February 1941): 47.

2 "How Hitler Deceives His People-A Picture Analysis," PM's Weekly (22 September 1940): 33-38.

3 This essay is adapted from my dissertation. Carol Payne, "Interactions of Photography and the Mass Media, 1920-1941: The Early Career of Ralph Steiner," Boston University, 1999. See specifically Chapter 5, "Challenges to Photographic 'Truth': Realism in Photography and the Threat of WWII Propaganda in Ralph Steiner's Criticism for PM's Weekly 1940-42," 217-69.

4 For a discussion of PMs use of radiophotos during the Second World War and the thorny question of photographic objectivity, see Jason Hill, "On the Efficacy of Artifice: PM, Radiophoto, and the Journalistic Discourse of Photographic Objectivity," Etudes photographiques 26 (November 2010): 71-85. My own work on $P M$-initiated in my dissertation-predates Hill's article, which cites my earlier study. The present article differs from Hill's work in the specific body of images chosen and in the close reading it provides of Steiner's columns.

5 For related recent discussion of propaganda and censorship in the British press in 1941 and 1942, see Jim Aulich, "Stealing the Thunder: The Soviet Union and Graphic Propaganda on the Home Front during the Second World War," Visual Culture in Britain (2012): 343-66.

6 J. Michael Sproule, Propaganda and Democracy: The American Experience of Media and Mass Persuasion (Cambridge: Cambridge University Press, 1997), 21, 155.

7 For a detailed study of the history of PM, see Paul Milkman, PM: A New Deal in Journalism, 1940-1948 (New Brunswick, NJ, and London: Rutgers University Press, 1997). For Life magazine, see Wendy Kozol, Life's America: Family and Nation in Postwar Photojournalism (Philadelphia: Temple University Press, 1994); Erika Doss, ed., Looking at Life Magazine (Washington: Smithsonian Institution Press, 2001); and Chris Vials, "The Popular Front in the American Century: Life Magazine, Margaret Bourke-White, and Consumer Realism, 1936-41," American Periodicals 16, 1 (2006): 74-102.

8 Michael Denning, The Cultural Front: The Laboring of American Culture in the Twentieth Century (New York: Verso, 1997), 84. In a biography, Roy Hoopes claims that Ingersoll was a member of the Communist Party years earlier. Roy Hoopes, Ralph Ingersoll: $A$ Biography (New York: Atheneum, 1985), 155-86.

9 Ralph McAllister Ingersoll papers, Special collections, Mugar Memorial Library, Boston University.

10 Vials notes that while Life was a vehicle for Luce's political conservatism, "the aesthetics of the magazine were stamped by those on the left, not least because Popular Front personnel were involved in its production." Vials, “The Popular Front," 77.
11 Vials usefully defines the Popular Front as "an international social and cultural movement initially set in motion by the Sovietdominated Communist International in order to combat the rising influence of fascism.... American communists forged alliances with other left and liberal organizations to create a common, prolabor, antiracist, and antifascist culture." Chris Vials, Realism for the Masses: Aesthetics, Popular Front Pluralism, and U.S. Culture, 1935-1947 (Jackson: University Press of Mississippi, 2009), xiii. Milkman, PM, 165-72.

12 Deborah E. Lipstadt, Beyond Belief: The American Press and the Coming of the Holocaust, 1933-1945 (New York: The Free Press, 1986), 37, 183, 186. Milkman, PM, 64

13 Milkman, $P M, 58,342$.

14 For a discussion of the news image, see Amy Lyford and Carol Payne, "Photojournalism, Mass Media and the Politics of Spectacle," Visual Resources: An International Journal of Documentation XXI, 2 (June 2005): 119-29.

15 For accounts of photojournalism's history in the United States, see Bonnie Brennen and Hanno Hardt, eds., Picturing the Past: Media, History, and Photography (Urbana and Chicago: University of Illinois Press, 1999); Michael L. Carlebach, American Photojournalism Comes of Age (Washington: Smithsonian Institution Press, 1997); and Marianne Fulton, Eyes of Time: Photojournalism in America (Boston: Little, Brown and Company Published in Association with the International Museum of Photography at George Eastman House, 1988).

16 Barbie Zelizer notes for example that the period saw a rise of some forty percent in the use of news pictures. Barbie Zelizer, Remembering to Forget: Holocaust Memory Through the Camera's Eye (Chicago: University of Chicago Press, 1998), 18.

17 Zelizer, Remembering to Forget, 18-20.

18 Barbie Zelizer, "When War is Reduced to a Photograph," in Reporting War: Journalism in Wartime, ed. Stuart Allan and Barbie Zelizer (London and New York: Routledge, 2004), 130.

19 For a discussion of the history of tabloid photojournalism, see Karin E. Becker, "Photojournalism and the Tabloid Press," in The Photography Reader, ed. Liz Wells (London and New York: Routledge, 2003), 291-308; Milkman, PM, 23.

20 Ralph Ingersoll, "A Discursive Outline of a Proposition to Invent a Daily Newspaper," 16 April 1937, PM papers, Box 1, Nieman Journalism Center, Harvard University.

21 Ralph Ingersoll, "Announcing a New Deal for Photographers," memo to PM photographers, 6 May 1941, 1. PM papers, Box 1, Nieman Journalism Center, Harvard University. Emphasis in the original.

22 See Alain Bergala, Miles Barth, and Ellen Handy, Weegee’s World (New York: Skira Rizzoli Publications in Association with the International Center of Photography, 1997); Anthony Lee, Weegee and Naked City (Berkeley: University of California Press, 2008); Margaret Bourke-White, Portrait of Myself: The 
Autobiography of Margaret Bourke-White (Boston: G.K. Hall \& Co., 1985).

23 The Sunday magazine also marks PMs most resilient legacy. Renamed Parade in the late 1940s, it was syndicated as a supplement to Sunday newspapers across the United States and is still published today.

24 Ralph McAllister Ingersoll papers, Special collections, Mugar Memorial Library, Boston University.

25 Payne, "Interactions."

26 Fiona M. Dejardin, "The Photo League: Left-wing Politics and the Popular Press," History of Photography 18, 2 (Summer 1994), 173.

27 Roland Barthes, "The Photographic Message" in Photography in Print, ed. Vicki Goldberg (Albuquerque: University of New Mexico Press, 1981), 523. More commonly, photo studies scholars turn to the Peircean concept of the index in discussing perceptions of photographic directness. Here, I have turned to classic essays by Roland Barthes and Stuart Hall as theoretical models for the material I discuss because they address photojournalism in very specific and concrete terms. As such, they provide subtle tools for understanding $P M$ s journalistic critique of photography.

28 William Stott, Documentary Expression and Thirties America (Chicago: University of Chicago Press, 1986), 73.

29 W.J.T. Mitchell, "The Photographic Essay: Four Case Studies," in Picture Theory: Essays on Verbal and Visual Representation (Chicago: University of Chicago Press, 1994), 284

30 Barthes, "The Photographic Message," 521-33

31 Ralph Steiner, "Look at These Pictures... Now Look at Next Page," PM's Weekly (4 August 1940): 47-49.

32 Barthes, "The Photographic Message."

33 Steiner, "What is Truth in Photography?"

34 Barthes, "The Photographic Message," 526.

35 Steiner, "What is Truth in Photography?"

36 For a discussion of the Roosevelt administration's complex response to the situation, see Steven Casey, Cautious Crusade: Franklin D. Roosevelt, American Public Opinion, and the War Against Nazi Germany (Oxford: Oxford University Press, 2001).

37 Max Lerner, "Propaganda’s Golden Age," The Nation (4 November 1939), 496

38 Harold D. Lasswell, Propaganda Technique in the World War (New York: Peter Smith, 1938). Sproule, Propaganda and Democracy, 21. Jacques Ellul's classic text on the subject argues for a more nuanced understanding of propaganda that recognizes the varying forms it takes. Ellul, Propaganda: The Formation of Men's Attitudes, trans. Konrad Kellen and Jean Lerner (New York: Vintage Books, 1973).

39 Lasswell, Propaganda Technique.

40 Sproule, Propaganda and Democracy, 129-31, 141. The IPA's papers are now held at the New York Public Library Archives, http:// archives.nypl.org/mss/1513 (accessed 16 December 2013).

41 Clyde Miller, quoted in Sproule, Propaganda and Democracy, 155.
42 Marianne Fulton, ed., Eyes of Time: Photojournalism in America (New York: New York Graphics Society, 1988).

43 Harold Lavine and James Wechsler, War Propaganda and the United States, rev. ed. (New York and London: Garland Publishing, Inc., [1940] 1972).

44 Leonard P. Liggio, "Introduction" to Lavine and Wechsler, War Propaganda, 11-12. Milkman, PM, 16-17.

45 Lavine and Wechsler, War Propaganda, 3.

46 Ralph Steiner, "Some Photographers Make England Look Like This... But Sensitive, Sensible Photographers Make England Look Like This," PM's Weekly (24 November 1940): 47-49. Steiner and $P M$ were not alone in presenting photographs to support Britain in mid-1941, the Museum of Modern Art mounted an exhibition depicting England during both World Wars. Edward Alden Jewell, "Exhibition at the Museum of Modern Art Graphically Presents Great Britain's Trial in This and the First World War," New York Times (1 June 1941): X7.

47 Ralph Steiner, "Some Photographers," 49.

48 Steiner, "Some Photographers," 37-39. Emphasis in the original.

49 Martin Jay, The Dialectical Imagination: A History of the Frankfurt School and the Institute of Social Research, 1923-1950 (Boston: Little, Brown, 1973), 166.

50 Quoted in Sproule, Propaganda and Democracy, 179. See Edgar Dale and Norma Vernon, "Introduction," Propaganda Analysis (Columbus, OH: Bureau of Educational Research, May 1940), i.

51 In surveying $P M$ s s chief competitors between 1 September and 6 October 1940, the period in which the photo-essay "How Hitler Deceives His People" ran, I found that the New York Times ran four Axis images while the New York Herald Tribune printed only two. The majority of both papers' pictorial coverage of the war came from Allied sources. Payne, "Interactions," Appendix.

52 Lipstadt, Beyond Belief, 6-7.

53 Lavine and Wechsler, War Propaganda, 35-36; Sproule, Propaganda and Democracy, 56; Brett Gary, "The Pitiless Spotlight of Publicity: Life Magazine and the WWII-Era Exposure of American Extremists," in Looking at Life, ed. Doss, 83-87.

54 Lipstadt, Beyond Belief, 124.

55 Barthes characterizes this relationship between image and text as "complementary." See Roland Barthes, "The Rhetoric of the Image," in Image/Music/Text, ed. and trans. Stephen Heath (New York: Hill and Wang, 1977), 40.

56 The terminology is adapted from Zelizer's discussion of atrocity photographs. Barbie Zelizer, "Holocaust Photography, Then and Now," in Picturing the Past: Media, History, and Photography, ed. Bonnie Brennen and Hanno Hardt (Urbana and Chicago: University of Chicago Press, 1999), 104. Zelizer, Remembering to Forget, 139.

57 Steiner, "If You Look at This Picture for Less than Three Minutes You Will Miss Part of Its Important Message," PM's Weekly (10 November 1940): 48-49.

58 Based on the H.G. Wells work of the same title. 
59 Ralph Steiner, "Study Nazi 'Art' with Open Eyes and Crossed Fingers," PM's Weekly (19 January 1941): 49.

60 Stuart Hall, "The Determinations of News Photographs," Working Papers in Cultural Studies 3 (Autumn 1972), 67.

61 "How Hitler Deceives His People," 33-38. Although there is no evidence that Steiner edited this pictorial, it adheres to the same strategies adopted in his column.

62 The most likely photographer of at least some of these images is Heinrich Hoffmann, an official photographer of the Nazi party. However, positive identifications were not located in the holdings of the US National Archives where many of Hoffmann's materials remain. I thank Richard Fustick, US National Archives (Photographs Division) for his assistance.

63 Deutschland erwacht: Werden, Kampf und Sieg der N.S.D.A.P., Berlin, [s.n.], 1933. Special Collections, Mugar Memorial Library, Boston University.

64 Ellul, Propaganda, 75.

65 Susan Sontag, "Fascinating Fascism," in Under the Sign of Saturn (New York: Farrar, Straus and Giroux, 1980), 91.

66 "How Hitler Deceives His People," 36.

67 "What We Are Fighting For," Picture Post, 13 July 1940. See also John Taylor, War Photography: Realism in the British Press (London: Routledge, 1991), 71-72.

68 Cécile Whiting, Antifascism in American Art (New Haven: Yale University Press, 1989), 17.

69 For more on Heartfield, see Andrés Mario Zervigón, John Heartfield and the Agitated Image: Photography, Persuasion, and the Rise of Avant-Garde Photomontage (Chicago: University of Chicago Press, 2012).

70 Members of the Frankfurt School were beginning to be read in the United States at roughly this time. For them, Nazi propaganda set the mechanisms of the culture industry in high relief. Theodor Adorno and Max Horkeimer's Dialectic of Enlightenment, for example, was originally published in 1944 .

71 Hall, “The Determinations of News Photographs," 67.

72 Milkman, $P M, 60-106$.

73 Lipstadt, Beyond Belief, 183, 214.

74 "Inside Poland: Smuggled Pictures Show Nazi Persecution," PM (5 February 1941): 15-19. Cited in Zelizer, Remembering to Forget, 43. For a detailed study of photography and the Holocaust, including images made in the Warsaw Ghetto, see Janina Struk, Photographing the Holocaust: Interpretations of the Evidence (London: I.B. Taurus, 2004).

75 Zelizer, Remembering to Forget, 39.

76 Susan A. Brewer, Why America Fights: Patriotism and War Propaganda from the Phillipines to Iraq (Oxford: Oxford University Press, 2009), 124-25.

77 For discussions of images of the Holocaust, see, among many other titles, Barbie Zelizer, ed., Visual Culture and the Holocaust (London: Athlone Press, 2001); Marianne Hirsch and Leo Spitzer, "The Wit- ness in the Archive: Holocaust Studies / Memory Studies," Memory Studies 2, 2 (May 2009): 151-70; Georges Didi-Huberman, Images in Spite of All: Four Photographs from Auschwitz, trans. Shane B. Lillis (Chicago: University of Chicago Press, 2008).

78 Susan Sontag, On Photography (New York: Delta, 1977), 20.

79 Struk, Photographing the Holocaust.

80 Zelizer, Remembering to Forget, 204.

81 Susan A. Crane, "Choosing Not to Look: Representation, Repatriation, and Holocaust Atrocity Photography," History and Theory 47 (October 2008): 309-30; Susan Sontag, Regarding the Pain of Others (New York: Farrar, Strauss, and Giroux, 2003). 